\author{
${ }^{1}$ Zh.O. Abikenov, ${ }^{2}$ S.E. Kudaibergenov \\ ${ }^{1}$ Korkyt Ata Kyzylorda State University, Kyzylorda, Kazahkstan \\ ${ }^{2}$ Al-Farabi Kazakh National University, Almaty, Kazakhstan \\ Corresponding Author: Abikenov Zh., abikenov-kuzultam@mail.ru
}

\title{
METHODS OF SEMIOTIC ANALYSIS OF CULTURAL VALUES
}

\begin{abstract}
The article is devoted to the analysis of the semiotic approach, which considers the key principles of the study of cultural values. The authors propose to systematize the methodological principles of the semiotic approach and understanding of culture as a structure consisting of a number of symbolic systems and cultural texts, cultural representativity and symbolic interpretation of culture signs and the concept of "value" as a key concept in the semantic system philosophy. On the basis of the correlation between the methodological principles of the semiotic approach and the ideas of constructivism, the definition of the concept of "value" is refined. Value is understood as a semiotic construction that generates social meanings in the consciousness of the individual and the collective and allows a person to check his ideas about the world around him and on a subconscious level, to construct his own picture of the world.
\end{abstract}

Key words: Cultural Approach, Constructivism, Culture, Value, Semiotica.

\section{Мәдени құндылықтарды семиотикалық талдаудағы әдістер}

\section{${ }^{1}$ Ж.О. Әбікенов, ${ }^{2}$ С.Е.Құдайбергенов}

${ }^{1}$ Қорқыыт Ата атындагы Қызыллорда университеті, Қызылорда, Қазақсстан ${ }^{2}$ Әл-Фараби атындавы Қазақ ұлттық университеті, Алматы, Қазақстан

Аннотация. Бұл мақала мәдени құндылықтарды зерттеудің негізгі принциптері болып саналатын семиотикалық тәсілді талдауға арналған. Автор семиотикалық көзқарас пен мәдениетті түсінудің әдіснамалық принциптерін жүйелік белгілерді жүйелік белгілер мен мәдени мәтіндерден тұратын құрылым ретінде жүйелеуді ұсынады. Мәдениеттің репрезентативтілігі және мәдени белгілерінің рәміздік түсіндірмесі және «құндылық» ұғымы семантикалық философиядағы негізгі ұғым ретінде береді. Семиотикалық көзқарастың корреляциясы негізінде әдіснамалық принциптер мен конструктивизм идеялары, «құндылық» анықтамасы көрсетілген. Құндылық жеке тұлғаның және ұжымның санасында әлеуметтік мағыналарды тудыратын және адамға қоршаған әлем туралы идеяларды тексеруге және бейсаналық деңгейде өзінің әлем суретін жобалауға мүмкіндік беретін семиотикалық құрылым ретінде түсініледі.

Түйін сөздер: мәдени әдіс, конструктивизм, мәдениет, құндылық, семиотика. 


\title{
Методы семиотического анализа культурных ценностей
}

\author{
${ }^{1}$ Ж.О. Абикенов, ${ }^{2}$ С.Е.Кудайбергенов \\ ${ }^{1}$ Кызылординский университет имени Коркыт Ата, Кызылорда, Казахстан \\ ${ }^{2}$ Казахский национальный университет имени аль-Фараби, Алматы, Казахстан
}

Аннотация. Данная статья посвящена анализу семиотического подхода, рассматривающего ключевые принципы изучения ценностей культуры. Автор предлагает систематизировать методологические принципы семиотического подхода и понимания культуры как структуры, состоящей из ряда символических систем и культурных текстов; культурная репрезентативность и символическая интерпретация знаков культуры и понятие «ценность» как ключевое понятие в семантической философии. На основе соотношения методологических принципов семиотического подхода и идей конструктивизма уточняется определение понятия «ценность». Ценность понимается как семиотическая конструкция, которая порождает социальные значения в сознании индивида и коллектива и позволяет человеку проверять представления об окружающем мире и на подсознательном уровне строить свою картину мира.

Ключевые слова: культурный подход, конструктивизм, культура, ценности, семиотика.

\section{Introduction}

According to Tarasti, «semiotics explores the content of signs, their use and the formation of meanings of signs at both the level of a single sign and the broader systems and structures formed by signs» [1, p. 1293].

The semiotic approach arises on the basis of philosophical hermeneutics and linguistic concepts, in particular the theory of the meaning of signs by Ferdinand de Saussure. The founder of semiotics as a general theory of sign structures is the American philosopher, logician, mathematician, philosopher and naturalist Charles Sanders Pearce. It was he who first created the classification of signs, highlighting sign, natural and conventional signs. Further development of the semiotic approach is associated with the research of L. Wittgenstein, H.G. Gadamer, R. Montague, C. Morris, R. Carnap, S. Kripke, L. Tarski and others.

The methodological principles of the cultural semiotic approach are systematized: understanding of culture as a structure consisting of a number of symbolic systems and cultural texts; the principle of symbolic creativity, actualized in artistic dialogism; representation of culture and symbolic interpretation of signs. culture; the concept of "value" as a key concept in the concept of the semantic philosophy of cultural values. Consideration of the cultural semiotic approach in conjunction with the ideas of constructivism made it possible to supplement the methodological principles of the approach to understanding the nature of cultural values. Cultural values are understood as a cultural-semiotic construct that gen- 
erates social meanings in the individual and collective consciousness. As a secondary constructive system, cultural values in their cultural and semiotic forms embody already existing and functioning primary constructions that embody cultural values.

\section{Research methods}

The methodology of the work includes such theoretical approaches as the system-structural method, the interdisciplinary method, the method of source study. The need for a different approach is a broader; more volume is to the study of cultural phenomena become apparent and urgent. In our view, such a methodological function can only perform cultural studies approach. This term includes two aspects of the study of cultural phenomena: cultural and logical.

According to Gilbert, «this explains the great interest that logic shows to the right conclusions. Correct reasoning like reverses and specifies our knowledge. It gives an absolute guarantee of success, rather than simply providing one or another perhaps even higher the probability of a true conclusion. However, this is subject to the decision of the main tasks of logic is correct reasoning. Only solution to this problem allows us to formulate the problem in a logical method for the study of cultural phenomena to truth» [2].

As you know the explanation of the author Uzakbaeva, «semiotic methodology is characterized by the allocation of three levels of study of sign systems: syntax, semantics and pragmatics. The syntactic structure studies combinations of signs and the rules for their formation, regardless of their meanings and functions of symbolic systems. Semantics studies sign systems as a means of expressing meaning from the point of view of the interpretation of signs and their combinations. Pragmatics studies the relationship between sign systems and those who perceive, interpret and use the information in these posts» [3].

According to founder of semiotics American logician Charles Pierce «gave a typology of signs, explored the functioning of signs, and questioned the value of the figure showed triadic nature of the sign, which later found its embodiment in three levels of semiotic analysis» [4]. However, a powerful impetus given by the development of semiotics, led to the emergence not only of a new discipline, but also a whole new methodological trends in science singled in a natural language system in its pure form, abstracted from language development and its external relations.

\section{The main theory}

Semiotics of culture is an area of research within the framework of semiotics that attempts to define culture from a semiotic point of view and as a type of human symbolic activity, the creation of signs and a way of giving meaning to everything around. 
In fact, some scholars suggest that everything can be analyzed semiotically; they see semiotics as the queen of interpretive sciences, the key that reveals the meaning of everything big and small [5].

Ferdinand de Saussure and Charles Sanders Pierce, Lotman are considered the founders of semiotics. Therefore, culture is understood here as a system of symbols or significant signs. Since the main sign system is the language system, it is usually called the semiotics of culture and language. Within this area of study, symbols are analyzed and classified according to a specific class in a hierarchical system.

While for the linguist Saussure, "semiology" was "the science that studies the role of signs as part of social life," for the philosopher Charles Peirce, "semiotics" was a "formal doctrine of signs" that was closely related to logic. For him, "a sign is something that means something to someone in some respect or quality." He stated that "every thought is a sign." Modern semiotics study signs not in isolation, but as part of semiotic "sign systems". They study how meanings are created: as such, engaging not only in communication, but also in the construction and maintenance of reality. The American scholar Charles S. Pearce and the Swiss linguist Ferdinand de Saussure are considered the founders of modern semiotics. Peirce's semiotics, different from Saussure's dyadic semiotics, is a kind of triadic semiotics. He defines a sign as a triad consisting of three indecomposable elements: representation, object and interpreter [6].

According to Peirce, a sign is something that for someone means something in some relation or ability. He addresses someone, that is, he creates in the mind of this person an equivalent sign or, perhaps, a more developed sign. The character it creates is what I call the interpreter of the first character. The sign denotes something, its object. It denotes this object, but not in all respects, but refers to some type of idea that I have sometimes called the basis of representation [7]. Peirce calls the interaction between the representative, the object and the interpreter semiosis [4].

Culture is primarily a semiotic system. One of the earlier definitions of a semiotic system can be found in Lotman's article, in which he defines a system as "a structure of elements and rules for their combination, which is in a state of fixed analogy with the entire sphere of the object of knowledge, understanding and regulation".

The peculiarity of language and culture in general is that from an early age we perceive them as an integral part of our life and rarely ask ourselves how they work, which becomes the focus of most of Lotman's semiotic works [8].

From the point of view of semiotics, any action that can be attributed to signs can also be called descriptive. Semiotics deals with descriptions, and any descriptive action can be the object of the semiotic stage [9]. 


\section{Results}

Based on the results of the analysis of theoretical studies of researchers studying the semiotics of culture, the methodological foundations of the semiotic approach will be streamlined. The first methodological principle of the semiotic approach is the understanding of culture as a structure consisting of a number of symbolic systems and cultural texts.

Extrapolating the aforementioned theoretical model of culture as a set of texts about cultural reality, we can single out a number of cultural texts that play an important role in the life of society. These are cultural and semiotic practices, by which we mean the number of social actions in which sign-symbolic forms of culture are produced, preserved and transmitted, bearing certain social values and meanings. By these semiotic practices, we mean art, cinema, media, political discourse, art criticism, etc. These texts represent an information structure that actively functions in society [10].

The second principle of the semiotic approach is the principle of symbolic creativity, actualized in artistic dialogism. The main idea behind this principle is "symbol". This is the ontogeny of the symbol, and its cognitive function, and, in contrast to the sign and the symbol, its hermeneutics and the symbolic nature of culture.

The founder of semiotics C.S. Pierce notes that the action of a symbol is based on the fact that the information encoded in it will be understood in a certain way by the person who interprets it [11]. According to N.L. Koretskaya, the ability of a symbol to fix, store and transmit information ensures its close connection with traditions, rituals and customs, and through them "the system of symbols is included in the national consciousness" [12] Yu.M. Lotman believes that a symbol has the ability to accumulate, consolidate and transmit information over many generations, acting as a custodian of the non-genetic cultural memory of people, rooted in the depths of the archaic [13].

Thus, the ability of symbols to have a certain meaning, as well as the ability to read and understand them, makes them cultural texts. According to K. Geertz, «it is necessary to study not the ontological status of the phenomena of our world, but their value, i.e. consider them in terms of their symbolic manifestation». The creation of a symbol, both the process of creating a cultural text and its perception by the subject, presupposes the disclosure of a certain message. In the realm of art, this message is often introduced by archaic images that act as symbols.

The third principle is related to the representativity of culture and the symbolic interpretation of the signs of culture.

The symbolic character of cultural texts determines the representative character of the culture as a whole. F. Tenbrook defines the representativeness of culture in its mediating role. He writes: "Culture is representative, that is, it produces ideas, meanings and values that act through their actual recognition. It covers those beliefs, views, worldview, ideas and ideologies that influence social 
action, because they are actively or passively shared or accepted" [14, p. 101]. Cultural codes that provide the transfer of social experience and information are a universal means of representation, structural organization and transfer of cultural experience, information and values. The fundamental role of the cultural form in these processes lies in the fact that it manifests itself as a message and a text.

The fourth principle of the semiotic approach is defined by the concept of "value" as one of the key values in the concept of semantic philosophy of cultural values. Cultural texts are important to individuals and society because of the content they represent.

Since our interest concerns the values of cultures, we share cultural values that determine the representative character of national art, and we give the following definition: cultural values are a certain cultural construct formed in historical dynamics that embodies the especially significant views of a cultural group. When studying the works of visual culture, the following cultural values were identified: 1) a single cultural and ideological basis; 2) specific types of cultural heroes characteristic of a particular cultural group; 3 ) ideas about the value-perfect type of personality; 4) the most relevant things; 5) unique cultural signs for different types of social communication. Thus, we propose to consider the work of subtle cultural values as a semiotic space of representation in sign-symbolic forms of cultural values, which serve as a powerful factor in the self-identification of an ethnic society in a multicultural system [10].

Thus, the semiotic approach as a methodological approach to the study of culture offers a special model of the relationship between culture as a social structure and a subject. According to this approach, culture is understood as a structure consisting of a number of symbolic systems and cultural texts, the representative and interpretive nature of which is actualized in the process of creating symbols and artistic dialogue. Important concepts of the cultural-semiotic approach are "symbol" and "value", which determine the representative character of cultural texts.

\section{Discussion}

The purpose of this section is to supplement and develop the methodological foundations of the semiotic approach based on an appeal to the theoretical ideas of constructivism, a direction that has become one of the most pressing problems of modern humanitarian knowledge at the beginning of the 21 st century. This is due to the fact that this approach is based on the actual idea of the symbolic production of ethnicity by means of cultural and semiotic practices.

It is obvious that cultural identity, constructed by the images of cultural texts, is transient, since it is constructed here and now in the process of artistic dialogue.

Cultural values are an equally important sphere of culture that has constructivist capabilities. Constructivist theory allows us to view cultural values as a 
semiotic construct that generates social meanings in individual and collective consciousness. Sign-symbolic forms of compositions are sensually present constructions of art. Thanks to symbols, a person has a symbolic "reality" with the help of which he builds a holistic picture of the world [15].

The task of the researcher in this case, according to K. Geertz, is to search, identify and clarify the meaning of the expressed social. He writes: "Analysis is the study of semantic structures, as well as the determination of their social basis and social significance" [16].

In every society, according to K. Geertz, «the sphere of culture consists of a number of cultural systems. There is a typical set of cultural systems that are repeated in most societies. These are the values of religion, ideology, politics, science and culture». On the basis of these cultural systems, or rather their impulses, a person forms a vision of the world, his own picture of the world. R. Iyerman, professor of sociology at Yale University, introduces the concept of "imagination space", which is constructed with the help of imagination and creativity, which are "directly related to the semantic dimension" [17].

Thus, cultural values are understood as a space of imagination, as a form of social reality that forms the basis of social identities and practices.

Semiotics do not always explicitly point out the limitations of their methods, and semiotics are sometimes presented uncritically as a general-purpose tool. The semiotic approach works better for some goals than for others, and makes it easier to ask certain types of questions than others. Empirical testing of semiotic statements requires a variety of techniques. Structuralist semiotic analysis is just one of many methods that can be used to investigate sign practices. In terms of textual analysis, other approaches include critical discourse analysis and content analysis. While semiotics is now closely associated with cultural studies, content analysis is firmly rooted in the mainstream tradition of social science research. Content analysis involves a quantitative approach to analyzing the explicit content of texts, while semiotics seeks to analyze texts as structured wholes and explores latent, connotative meanings. Semiotics often reject quantitative approaches: the fact that an element is often found in a text or in cultural practice does not make it significant. While content analysis focuses on explicit content and tends to assume that it represents a single fixed meaning, semiotic research focuses on the system of rules governing discourse involved in texts and practices, emphasizing the role of semiotic context in the formation of meaning [6].

Consideration of the semiotic approach in conjunction with the ideas of constructivism made it possible to supplement the methodological principles of the approach to understanding the essence of cultural values. Cultural values are understood as a semiotic construction that generates social meanings in the individual and collective consciousness. 


\section{Conclusion}

Semiotics is a methodology because it can explain the origin and effectiveness of any meaning that any social discourse ascribes to any phenomenon. The emergence and effectiveness of a given value is always problematic, so they need to be explained. All explanations imply the previous problematization of the meaning of the phenomenon; the content of the explanation and the process of problematization are subjective and ideological actions.

Methodology is critical in any field of science because an unreliable method produces unreliable results and, as a consequence, undermines the cultural values of your interpretation of the results. In most cases, there are many different methods that you can choose to investigate a research problem. The reader wants to know that the data has been collected or obtained in a manner that is consistent with accepted research practice. The method should be consistent with the general objectives of the study. The methodology should discuss the expected problems and the steps you have taken to prevent them.

Nowadays one of the most actual problems of culture science is to develop methodological approaches to the study of culture values. Methodology is the theory of historical knowledge and cognition, closely connected with the techniques of culture investigation the basic of any scientific research.

\section{References}

1. Eero Tarasti. Communication understanding. - Tartu, Printed by Greif, 2009. - P. 1293.

2. Gilbert J. Against the Commodification of Everything. Cultural Studies, 2008. 22 (5). - P. 55-56.

3. Uzakbaeva S.A. Concept ethno pedagogical education high school students. Almaty, 1998. - P. 11.

4. Peirce C.S. The Essential Peirce: Selected Philosophical Writings, vol. 2. Bloomington. IN: Indiana University Press, 1998. - P. 412.

5. Melahat Arıklı. Science of Semiology: Apply to an Event. International Review of Management and Marketing, 2016. - P. 1074-1079.

6. Chandler Daniel. Semiotics the basics. Routledge. - New York, 2002. - P. 326.

7. Peirce C.S. Collected papers of Charles Sanders Peirce. Volume II. - Cambridge: Harvard University Press, 1960. - P. 28.

8. Semenenko A. The texture of culture an introduction to Yuri Lotman's semiotic Theory. Palgrave macmillan. - New York, 2012. - P. 22.

9. Eero Tarasti. From nature to psyche. - Helsinki, Printed by Hakapiano, 2004. - P. 192.

10. Seredkina N. Revisiting Methodological Principles of Cultural-Semiotic Approach in Studying Art of Indigenous Peoples of the North, Siberia and the Far East // Journal of Siberian Federal University. Humanities \& Social Sciences, 2014. - 1342-1357 pp.

11. Peirce Ch. Logical Groundings of the Theory of Signs. - Saint-Petersburg, the Metaphysics Research Laboratory of Philosophic Department of SPbSU, Aleteiia, 2000. $-352 \mathrm{p}$. 
12. Koretskaia N.L. Simbol in National Culture. Definition of Culture, 1998. - P. 80.

13. Lotman Y.M. Inside the Thinking Worlds. - Moscow, 1996. - $464 \mathrm{c}$.

14. Tenbruk F. Representative Culture. Sociological Survey, 2013. - №12 (3), 93$120 \mathrm{pp}$.

15. Lola G.N. Aura Production: Creativity and/or Creative // International Journal of Cultural Studies, 2011. - №2 (3). - P. 38-43.

16. Geertz C. The Interpretation of Cultures. Rossiiskaia politicheskaia entsiklopediia. - Moscow, 2004. - 560 p.

17. Fen E. Ron Iyerman. To the Meaning Oriented Sociology of Art. Sociological Survey. - 2010. - №9 (2). - 75-80 pp.

INFORMATION ABOUT AUTHORS

\begin{tabular}{|l|l|}
\hline Zharkynbek Abikenov & $\begin{array}{l}\text { PhD, Senior Lecturer, Korkyt Ata Kyzylorda State } \\
\text { University, Kyzylorda }\end{array}$ \\
\hline Sergazy Kudaibergenov & $\begin{array}{l}\text { Master, lecturer, Al-Farabi Kazakh National } \\
\text { University, Almaty }\end{array}$ \\
\hline
\end{tabular}

\begin{tabular}{|l|l|}
\hline Жарқынбек Әбікенов Оралбекұлы & $\begin{array}{l}\text { PhD, ава оқытушы, Қорқыт Ата атындагы } \\
\text { Қызылорда университеті, Қызылорда, }\end{array}$ \\
\hline Сергазы Ережепұлы Құдайбергенов & $\begin{array}{l}\text { Магистр, оқытушиы, дл-Фараби атындавы Қазақ } \\
\text { ұлттықық университеті, Алматы }\end{array}$ \\
\hline
\end{tabular}

\begin{tabular}{|l|l|}
\hline Жаркынбек Абикенов Оралбекович & $\begin{array}{l}\text { РhD, старший преподаватель, Кызылординский } \\
\text { университет имени Коркыт Ата, Кызылорда }\end{array}$ \\
\hline Сергазы Ережепулы Кудайбергенов & $\begin{array}{l}\text { Магистр, преподаватель, Казахский националь- } \\
\text { ный университет имени Аль-Фараби, Алматы }\end{array}$ \\
\hline
\end{tabular}

Ссылка на данную статью: Abikenov Zh., Kudaibergenov S. Methods of Semiotic Analysis of Cultural Values // Адам әлемі. - 2021. №1(87), cc. 102-110. 